\title{
Reproductive Biology of Oligosarcus argenteus (Gunther, 1864) Adult Males and Description of the Gonadal Maturation Stages
}

\author{
Sérgio Luis Pinto da Matta ${ }^{1 *}$, Marcos de Lucca Moreira Gomes ${ }^{1}$ and Dálcio Ricardo de \\ Andrade $^{2}$ \\ ${ }^{I}$ Departamento de Biologia Geral; Universidade Federal de Viçosa, Av. Ph Rolfs, s/n; 36570-000; Viçosa - MG - \\ Brasil. ${ }^{2}$ Universidade Estadual do Norte Fluminense; Av. Alberto Lamego, 2000; 28013-600; Campos dos \\ Goytacazes - RJ - Brasil
}

\begin{abstract}
Oligosarcus argenteus belongs to the Acestrorhynchinae subfamily, being restricted to South America, and found in several Brazilian hydrographic basins, in lotic and lentic environments, where they are able to reproduce. With the purpose of studying the reproductive biology of the males from this species, many morphological parameters were analyzed during a 24 month period, as well as characterizing the different testicular maturation stages. A maturity scale, with three stages (I - Initial Maturing, II - Intermediate Maturing, III - Final Maturing) was proposed for the adult males of Oligosarcus argenteus. The reproductive period was established by the bimonthly frequency of spermatogenesis and by the gonadal maturation stages.
\end{abstract}

Key words: Reproductive cycle, histology, testis, Oligosarcus argenteus

\section{INTRODUCTION}

The preservation, distribution, and population abundance of teleost fishes have been well studied in the past (Schulz and Martins-Junior, 2001; Uieda and Uieda, 2001; Schifino et al., 2004; Siqueira-Souza and Freitas, 2004). The reproductive cycle and the gametogenesis are important parameters used in the understanding of the native fish species reproduction processes, and in the establishment of conservation programs (Bazzoli and Godinho, 1991; Vazzoler, 1996). The annual cyclic activity of teleosts is arranged in a variable number of stages, considering different morphological and physiological criteria. Many studies have been made with the testicular cycle of teleost fishes (Ferrari, 1981; Andrade and Godinho, 1983; Silva, 1987; Azevedo et al., 1988; Patzner et al., 1991; Fraile et al., 1992; Modesto and Canário, 2002; Chaves-Pozo et al., 2005; Cruz-Landim et al., 2005), but there are still some questions about the reproductive cycle of many other species.

The bocarra (Oligosarcus argenteus) is the species currently found in many hydrographic Brazilian bays, in lotic and lentic environments, where they are able to reproduce (Souza and Andrade, 1984). It belongs to the Order Characiformes, subfamily Acestrorhynchinae, which is restricted to the South

\footnotetext{
* Author for correspondence: smatta@ufv.br
} 
American continent (Menezes, 1972). This species shows high reproductive rates, being used in biological control of proliferous fish as tilapia (Souza and Andrade, 1984).

In the past, many studies have been done about the production (Silva, 1990), nutrition, ecology, reproductive cycle (Santos, 1993; Andrade et al., 1995, Santos et al., 1995), morphological (Matta et al., 1994), and histochemical characterization (Neves et al., 1991, 1995, 1996) of O. argenteus.

The aim of this study was to describe the reproductive cycle and the testicular morphology of $O$. argenteus, giving additional information that could be used in later phylogenetic studies. These data aimed at improving the knowledge concerning the reproductive biology of the males in the Characiformes order.

\section{MATERIALS AND METHODS}

Male specimens of $O$. argenteus were monthly sampled during two years (from October 1990 to September 1992) from the water tanks of the Pisciculture and Hydrobiology Station of the Federal University of Viçosa, Minas Gerais, Brazil $\left(20^{\circ} 45^{\prime} \mathrm{S}\right.$ e $\left.42^{\circ} 51 \mathrm{~W}\right)$. From an initial lot of 500 animals, eight specimens were collected per month and transported alive to the laboratory, and then denervated by spinal section. For each individual the total (TL) and the standard (SL) body length, (in centimeters), body weight (BW) (in grams), and the gonadal maturation stages, estimated by macroscopical observation of the gonadal volume and color were measured. The dissected gonads were weighed, fixed in Bouin liquid, and embedded in paraffin. The $5 \mu \mathrm{m}$ slides were stained with hematoxilin and eosin. The PSP (Picrosirius-polarization) and Gomori reticulin techniques were used for the characterization of the distribution of collagen I and III in the testis. Three stages of gonadal maturation for the testicular cycle study, according to the frequency of testicular components: I - Initial Maturation, II - Intermediate Maturation and III - Final Maturation were considered. The bimonthly mean values of the Gonadosomatic Index (GSI) and of the testicular elements frequency were used to establish the maturation curve. The GSI was obtained dividing the gonadal weight by the body weight and multiplying the result by 100 . The volumetric proportions of the testicular elements were calculated using a Zeiss KPL 10 ocular lens that had a Gahm grid (Sala et al., 1982). This grid was constituted by 5 lines and 25 points. For each animal, 20 histological fields were examined, which were analyzed horizontally. The incidence of points that were situated over primary and secondary spermatogonia, primary and secondary spermatocytes, spermatids, spermatozoa, interstice and tubular wall, Sertoli cells, lumen and Leydig cells were considered.

\section{RESULTS}

The testes of $O$. argenteus were paired, elongated, laterally flattened organs (Fig 1A), and were accommodated inside the body cavity, forming pronounced folds, one on the mean third and the other in the caudal third of the body. They showed similar lengths, and were separated along their trajectory and met next to the urogenital papilla forming the spermatic duct. The testicular surface was smooth, and the color and volume varied in accordance with the stage of gonadal maturation. The testis coloration varied from white to yellow in the majority of the animals collected in colder and dryer months and during the rainy and hot periods they showed a white-milky color.

The testes were formed by the wound and anastomosed seminiferous tubules, which presented variable shapes and volumes. There was a connective tunica, the albuginea, with plenty of collagen (Fig. 1C) surronding the testis, of which septs were originated responsible for the testis internal division in incomplete lobules. These lobules were responsible for the seminiferous tubules sustentation. The septs formed the interstice and were composed of a smooth connective tissue, with an abundant net of blood vessels, Leydig cells, and reticular fibers. (Fig 1B and $\mathrm{C}$ ).

Spermatogenic cell cysts, which were surrounded by Sertoli cells, formed the seminiferous tubule wall, and in each cyst, the germ cells were in the same maturation stage.

The biometric measurements were made along the bimesters, presenting the following variations: total length $(7.63-11.98 \mathrm{~cm})$, standard length $(6.22-$ $10,19 \mathrm{~cm})$, body weight $(4.21-18.32 \mathrm{~g})$, gonadal weight $(0.07-0.378 \mathrm{~g})$. The highest GSI mean value was observed between August/September 1992 and the lowest between February/March 1991 (Table 1). 
Table 1 - Morphometric data bimonthly grouped for adult males of $O$. argenteus. TL = total length, SL = standard length, BW = body weight, GW = gonadal weight, and GSI = gonadosomatic index (mean \pm standard error).

\begin{tabular}{|c|c|c|c|c|c|}
\hline Month/year & TL $(\mathbf{c m})$ & $\mathrm{SL}(\mathbf{c m})$ & BW (g) & GW (g) & GSI $(\%)$ \\
\hline Oct/Nov - & $10.47 \pm 0.757$ & $8.93 \pm 0.724$ & $10.42 \pm 1.99$ & $0.153 \pm 0.032$ & $1.468 \pm 0.35$ \\
\hline Dec/Jan -1991 & $9.99 \pm 1.2$ & $8.44 \pm 0.878$ & $10.95 \pm 2.869$ & $0.152 \pm 0.051$ & $1.388 \pm 0.65$ \\
\hline Feb/Mar - & $10.55 \pm 0.507$ & $9.21 \pm 0.675$ & $12.74 \pm 1.19$ & $0.123 \pm 0.002$ & $0.965 \pm 0.10$ \\
\hline Âpr/May - & $11.46 \pm 1.24$ & $9.94 \pm 1.01$ & $17.51 \pm 4.72$ & $0.184 \pm 0.066$ & $1.051 \pm 0.13$ \\
\hline Jun/Jul - 1991 & $11.58 \pm 0.841$ & $9.70 \pm 0.694$ & $16.22 \pm 3.038$ & $0.225 \pm 0.073$ & $1.387 \pm 0.32$ \\
\hline Aug/Sep - & $11.95 \pm 2.06$ & $10.09 \pm 1.47$ & $16.25 \pm 6.415$ & $0.312 \pm 0.156$ & $1.920 \pm 0.59$ \\
\hline Oct/Nov - 1991 & $11.61 \pm 1.61$ & $9.84 \pm 2.195$ & $15.71 \pm 6.258$ & $0.268 \pm 0.079$ & $1.706 \pm 0.70$ \\
\hline Dec/Jan - 1992 & $11.98 \pm 0.817$ & $10.19 \pm 0.804$ & $18.32 \pm 2.682$ & $0.378 \pm 0.117$ & $2.063 \pm 0.72$ \\
\hline Feb/Mar - & $7.63 \pm 0.59$ & $6.22 \pm 0.536$ & $4.21 \pm 0.492$ & $0.0713 \pm 0.025$ & $1.694 \pm 0.59$ \\
\hline Âpr/May - & $9.00 \pm 0.623$ & $7.48 \pm 0.526$ & $7.76 \pm 1.194$ & $0.168 \pm 0.041$ & $2.165 \pm 0.50$ \\
\hline Jun/Jul - 1992 & $9.53 \pm 0.99$ & $8.05 \pm 0.899$ & $9.1 \pm 2.403$ & $0.147 \pm 0.059$ & $1.615 \pm 0.51$ \\
\hline Aug/Sep - & $9.29 \pm 0.811$ & $7.87 \pm 0.727$ & $9.81 \pm 1.873$ & $0.218 \pm 0.061$ & $2.222 \pm 0.56$ \\
\hline
\end{tabular}

\section{Testicular Maturation Stages \\ Stage I - Initial}

During this phase, the testes were thin and clear, becoming pale and larger during their development. The seminiferous wall was thick, mainly formed by the primary spermatogonia cysts (Fig 1D). These were the biggest spermatogenic cells, presenting less condensed chromatin, an evident nucleolus and they were isolated within the cyst.

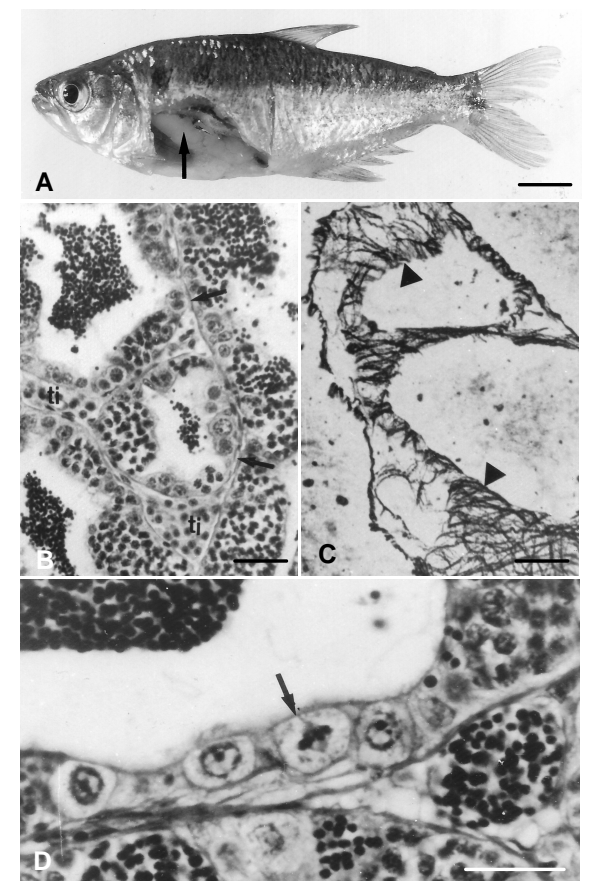

Figure 1 - A. Lateral view of $O$. argenteus adult male, showing the testis inside the body cavity (arrow). B-D. Transversal sections of seminiferous tubules. B. General testes organization, showing the interstitial tissue (ti), and the seminiferous tubules (arrows). C. Reticular fibers in the intertubule tissue (arrow heads). D. First testicular maturation stage, where we see the seminiferous tubule wall constituted by primary spermatogonia cysts (arrows). $\mathrm{ti}=$ intertubule tissue. Bars: $\mathrm{A}=1 \mathrm{~cm} ; \mathrm{B}-\mathrm{D}=21 \mu \mathrm{m}$ 
A variable number of secondary spermatogonia were observed inside the cysts (Fig. 2A), occurring together with the primary and secondary spermatocytes cysts and with spermatid cysts. Often empty tubules, adjacent to tubules full of spermatozoa were observed (Fig. 2B). In this stage, especially in the spermatogonia cysts, the presence of Sertoli cells was easily observed, which presented a triangular nucleus with an evident nucleolus (Fig. 2C). The GSI value was $1.87 \%$ (Table 2), and the mean spermatozoa volumetric proportion was $3.23 \%$, against $10.18 \%$ for the spermatogonia, $27.24 \%$ for the primary spermatocytes, and $21.93 \%$ for the secondary spermatocytes/spermatids (Table 3 ).

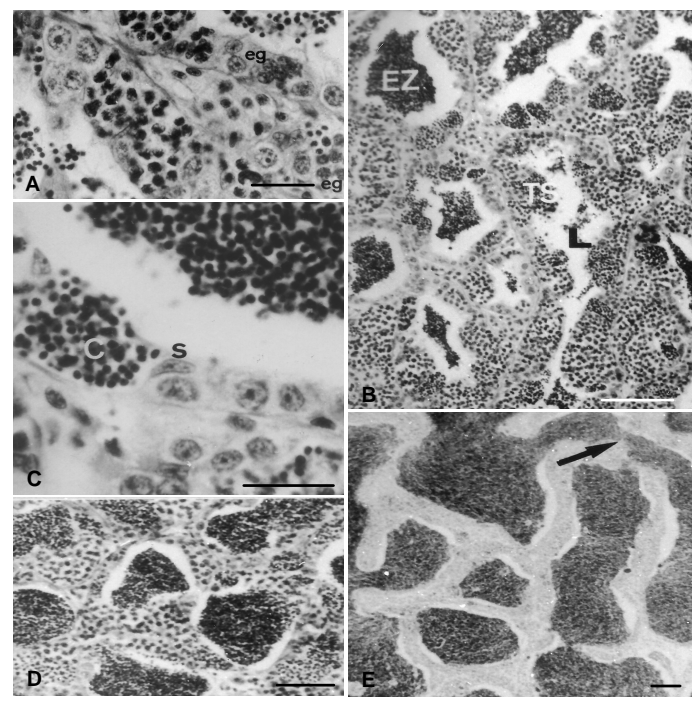

Figure 2 - Light microscopy of $O$. argenteus testes in different maturation stages. The figures A-C shows the Stage I of testicular maturation. A. We note a variable number of secondary spermatogonia (eg) inside the cysts. In Fig. B empty seminiferous tubules (TS) were observed, as well as those with few spermatozoa (EZ) inside the lumen (L). C. Sertoli cells (S) and round spermatids cysts (C). The Fig. D shows the Stage II of maturation, with tubules presenting thinner walls and a great spermatozoon mass. In Fig $\mathbf{E}$ we see the Stage III of maturation, showing lumens full of spermatozoa (EZ) and tubular anastomoses (arrow). Bars: $\mathrm{A}$ and $\mathrm{C}=15 \mu \mathrm{m} ; \mathrm{B}, \mathrm{D}$ and $\mathrm{E}=45 \mu \mathrm{m}$.

Table 2 - GSI (gonadosomatic indexes) per reproductive stage (RE), and number (n) of sampled adult males of $O$. argenteus (mean \pm standard error).

\begin{tabular}{ccc}
\hline $\mathbf{R E}$ & $\mathbf{n}$ & GSI \\
\hline 1 & 93 & $1.87 \pm 0.58$ \\
2 & 39 & $1.66 \pm 0.61$ \\
3 & 63 & $1.67 \pm 0.74$ \\
\hline
\end{tabular}

Table 3 - Volumetric proportions (\%) of spermatogenetic cells per reproductive stages (RE) of males O. argenteus. SPTG = spermatogonias, SPTC I = primary spermatocyte, SPTC II/SPTD = secondary spermatocyte/spermatid, SPZ $=$ spermatozoa $($ mean \pm standard error $)$.

\begin{tabular}{lcccc}
\hline RE & SPTG & SPTC I & SPTC II/SPTD & SPZ \\
\hline 1 & $10.18 \pm 4.06$ & $27.24 \pm 8.26$ & $21.93 \pm 7.91$ & $3.23 \pm 2.27$ \\
2 & $5.12 \pm 2.08$ & $20.34 \pm 7.14$ & $21.96 \pm 6.63$ & $19.63 \pm 13.88$ \\
3 & $5.32 \pm 2.13$ & $15.81 \pm 5.61$ & $17.33 \pm 5.08$ & $36.88 \pm 8.30$ \\
\hline
\end{tabular}




\section{Stage II - Intermediate Maturation}

The gonads became more voluminous and opaque, and presented a white-pale color. The spermatogenic activity increased and a large number of primary and secondary spermatocytes cysts and spermatids cysts were observed. The seminiferous tubules walls were thinner than in the Stage I, presenting spermatozoa accumulation (Fig. 2D).

During this stage, the GSI reached $1.66 \%$ (Table 2 ) and the mean spermatozoon volumetric proportion was $19.63 \%, 5.12 \%$ for spermatogonia, $20.34 \%$ for primary spermatocytes, and $21.96 \%$ for secondary spermatocytes/spermatids (Table 3).

\section{Stage III - Final Maturation}

In this phase, the gonads were opaque and pale, and there was a maximum of spermatozoa production. The seminiferous tubules walls tore, promoting intense anastomoses between them and causing large spermatozoa accumulation. (Fig. 2E). Within the seminiferous tubule walls, the cysts of all the spermatogenesis cell phases were observed. The GSI reached $1.67 \%$ (Table 2) and the mean spermatozoa volumetric proportion occupied by these cells was higher, reaching $36.88 \%$, against $5.32 \%$ of spermatogonia, $15.81 \%$ of primary spermatocytes and $17.33 \%$ of secondary spermatocytes/spermatids (Table 3). Considering the spermatogenic cell volumetric proportions and the gonadal maturation stages the reproductive period of $O$. argenteus occurred between October and March (Table 4).

Table 4 - Bimonthly frequencies of spermatogenetic cells in the testes of Oligosarcus argenteus. SPTG = spermatogonias, SPTC I = primary spermatocyte, SPTC II/SPTD = secondary spermatocyte/spermatid, SPZ = spermatozoa.

\begin{tabular}{lcccc}
\hline Month/Year & SPTG & SPTC I & SPTC II/SPTD & SPZ \\
\hline Oct/Nov - 1990 & 9.2 & 15.3 & 23.2 & 26.0 \\
Dec/Jan -1991 & 6.2 & 12.5 & 18.3 & 34.9 \\
Feb/Mar - 1991 & 6.5 & 17.9 & 19.6 & 29.4 \\
Apr/May - 1991 & 8.7 & 14.3 & 21.1 & 28.3 \\
Jun/Jul - 1991 & 8.3 & 24.0 & 24.6 & 12.1 \\
Aug/Sep - 1991 & 10.8 & 21.1 & 30.8 & 2.5 \\
Oct/Nov - 1991 & 4.9 & 12.9 & 26.4 & 24.2 \\
Dec/Jan - 1992 & 3.6 & 20.3 & 17.5 & 25.2 \\
Feb/Mar - 1992 & 4.4 & 22.4 & 14.8 & 35.4 \\
Apr/May - 1992 & 9.8 & 28.9 & 17.7 & 2.3 \\
Jun/Jul - 1992 & 7.9 & 32.4 & 13.7 & 4.8 \\
Aug/Sep - 1992 & 11.9 & 29.5 & 19.0 & 6.2 \\
\hline
\end{tabular}

\section{DISCUSSION}

The testicular morphology of $O$. argenteus was similar to the one described for the majority of the teleosts (Andrade, 1980; Ferrari, 1981; Bazzoli, 1985; Silva, 1987; Andrade, 1990; Cruz and Santos, 2004; Hojo et al., 2004, Santos et al., 2004), with no accessory organs as occurs in other fish species (Chacon and Mendes-Filho, 1972; Van den Hurk et al., 1987; Patzner, 1989; Lahnsteiner et al., 1993; Lau and Sadovy, 2001). Grier et al. (1980) described two testicular patterns based on the spermatogonia distribution along the seminiferous tubules. In Atheriniformes, the spermatogonia are restricted to the distal portion of the seminiferous tubules. However, in Salmoniforms, Perciforms and Cypriniforms, these cells are distributed along all the tubular structure. This last type, called spermatogonial unrestricted is also found in $O$. argenteus. Apparently the presence of spermatogonia inside the seminiferous tubules throughout the year acted as a spermatogenic cell reposition source, as suggested by other authors (Ferrari, 1981; Andrade and Godinho, 1983; Bazzoli, 1985; Tavares, 1986; Azevedo et al., 1988; Buxton 1990; Ferreira and Godinho, 1990; Pecio and Rafinski, 1994; Burns et al. 1995). The spermatogenic cells frequently 
indicated that the reproductive period of $O$. argenteus extended from October to March, as occurred with several tropical fish species in the southern hemisphere. Apparently the males of this species are able to reproduce at any time of the year, because of the presence of spermatogonia and spermatozoa inside the seminiferous tubules during this period. However, the reproductive phase can be associated with the female ovarian maturation period, according to Santos et al. (1995).

A spermatic duct surrounded by Sertoli cells, beginning in the mean third of the gonad and advancing until the final third was observed, as described by Andrade (1980) for Leporinus silvestrii. The Gonadosomatic Index (GSI) is an index used for the reproductive period determination in a large amount of animal species, including the fishes. The variation of their values is directly related to the periods of spermatozoa production, extrusion and absorption and provides data for the reproductive effort of the species (Le Cren, 1951; Mazzoni et al., 2002).

Barbieri (1981) and De Vlaming et al. (1982) accepted that the GSI should be the best reproductive period indicator, presenting peaks in specific months. In $O$. argenteus this index was not a good indicator because it did not present variation during the sampled months. This could be explained by the resource availability, wide photoperiod, and high temperatures along the year (Mazzoni et al., 2002). Nevertheless, other teleost species as Characidium sp. (Mazzoni et al., 2002) and Moenkhausia intermedia (Hojo et al., 2004) presented indexes that varied in accordance with the reproductive cycle period, with higher values during the hottest months.

The utilization of spermatogenic cell morphometry as a reproductive stage indicator allowed to determine the three stages of the $O$. argenteus reproductive cycle. These results differed from other authors who found four or five stages (Modesto and Canário, 2002; Cruz-Landim et al., 2005). Results didn't show a gonadal rest period and consequently a gonadal recrudescence period, as found in other teleost species (Chaves-Pozo et al., 2005).

\section{ACKNOWLEDGEMENTS}

We would like to thank Prof. Dr. Paulo Roberto Cecon for the help in the statistic analyses and
MS. Vinícius Albano Araújo for the suggestions and assistance on this work.

\section{RESUMO}

Oligosarcus argenteus é uma espécie pertencente à subfamília Acestrorhynchinae, restrita à América do Sul, sendo comumente encontrada nas várias bacias hidrográficas brasileiras, em ambientes lóticos e lênticos, onde se reproduzem. Com o objetivo de estudar a biologia reprodutiva de machos desta espécie, vários parâmetros morfológicos foram analisados durante um período de 24 meses, assim como foram caracterizados os diferentes estádios de maturação testicular. Estes foram descritos, considerando-se exemplares adultos, em: Estádio I - Maturação Inicial, Estádio II - Maturação Intermediária e Estádio III Maturação Final. Pela freqüência bimestral das células germinativas e dos estádios de maturação gonadal, a época de reprodução foi determinada.

\section{REFERENCES}

Andrade, D. R. (1980), Variação cíclica anual da espermatogênese em Leporinus silvestrii (Boulenger, 1902) Peixe, Teleósteo. Tese de Doutorado, Instituto de Ciências Biológicas Universidade Federal e Minas Gerais, Belo Horizonte, Brasil

Andrade, D. R. (1990), Biologia reprodutiva da manjuba Curimatella lepidura Eigenmann and Eigenmann, 1889 (Pisces, Curimatidae) da Represa de Três Marias, Rio São Francisco, MG. Tese de Doutorado, Instituto de Ciências Biológicas, Universidade Federal de Minas Gerais, Belo Horizonte, Brasil

Andrade, D. R. and Godinho, H. P. (1983), Annual male reproductive cycle of the Brazilian teleost fish Leporinus silvestrii (Boulenger, 1902). Arch. Biol. (Bruxelles), 94, 1-14

Andrade, D. R., Santos, A. A., Matta, S. L. P. (1995), Estádios de maturação ovariana de lambari Oligosarcus argenteus. Anais do Encontro Brasileiro de Ictiologia, G3-G3

Azevedo, C. O., Barbieri, M. C., Barbieri, G. (1988), Ciclo reprodutivo de Parodum tortuosus (Eigenmann and Norris, 1900) do Rio Passa-cinco, Ipeúna - SP. I. Estádios de maturação dos testículos e época de reprodução. Rev. Brasil. Biol., 48(3), 565-569

Barbieri, M. C., Barbieri, G., Marins, M. A. (1981), Sobre a anatomia e histologia do testículo de Geophagus brasiliensis (Quoy and Gaimard, 1824) 
na Represa do Lobo, Estado de São Paulo. Rev. Brasil. Biol., 41(1), 169-73

Bazzoli, N. (1985), Biologia reprodutiva do peixecachorro Acestrohyncus lacustris (Reinhardt, 1874) (Characidae, Acestrorhynchinae) da represa de Três Marias, rio São Francisco, MG. Tese de Mestrado, Instituto de Ciências Biológicas da Universidade Federal de Minas Gerais, Belo Horizonte, Brasil

Bazzoli, N., Godinho H. P. (1991), Reproductive biology of the Acestrorhynchus lacustris (Reinhardt, 1874) (Pisces, Characidae) from Três-MariasReservoir, Brazil. Zoolog. Anz., 226 (5-6), 285-297.

Burns, J. R.,Weitzman, S. H., Grier, H. J., Menezes, N. A. (1995), Internal fertilization, testis and sperm morphology in glandulocaudine fishes (Teleostei: Characidae: Glandulocaudinae). J. Morphol., 224, 131-145

Buxton, C. D. (1990), The reproductive biology of Chrysoblephus laticeps and C. cristiceps (Teleostei: Sparidae). J. Zool. Lond., 220, 497-511.

Chacon, J. O. and Mendes-Filho, A. (1972), Estudos do aparelho genital de cangati Trachycorystes galeatus Linnaeus, 1756. Ci. Cult., 24(6), 531-536.

Chaves-Pozo, E., Mulero, V., Mesenguer, J., Ayala, A. G. (2005), An overview of cell renewal in the testis throughout the reproductive cycle of a seasonal breeding teleost, the gilthead seabream (Sparus aurata L.). Biol. Reprod., 72, 593-601

Cruz, R. J. G., Santos, J. E. (2004), Testicular structure of three species of neotropical freshwater pimelodids (Pisces, Pimelodidae). Rev. Brasil. Zool, 21(2), 267271.

Cruz-Landim, C., Abdalla, F. C., Cruz-Höfling, M. A. (2005), Morphological changes of Sertoli cells during the male reproductive cycle of the teleost Piaractus mesopotamicus (Holmberg, 1887). Braz. J. Biol, 65(2), 241-249

De Vlaming, V. L., Grossman, G., Chapman, F. (1982), On the use of gonadosomatic index. Comp. Biochem. Physiol., 73A(1), 31-39

Ferrari, O. (1981), Variação sazonal da espermatogênese em traíra (Hoplias malabaricus Bloch, 1974), Peixe teleósteo. Tese de Mestrado. Instituto de Ciências biológicas, Universidade Federal de Minas Gerais, Belo Horizonte, Brasil

Ferreira, R. M. A. and Godinho, H. P. (1990), Reproductive biology of the white-piau, Schizodon knerii (Steindachner, 1875)(Anostomidae) from a reservoir in southeast Brazil. Eur. Arch. Biol. (Bruxelles), 101, 331-344.

Fraile, B.; Sáez, F. J.; Vicentini, C. A.; De Miguel, M. P.; Paniagua, R. (1992), The testicular cycle of Gambusia affinis holbrooki (Teleostei: Poecilidae). J. Zool. Lond., 228, 115-126

Grier, H. J. Leiton, J. R., Leatherland, J. F., De Vlaming, V. L. (1980), Structural evidence for two different testicular types in teleost fishes. Amer. J. Anat., 159, 331-345
Hojo, R. E. S., Santos, G. B., Bazzoli, N. (2004), Reproductive biology of Moenkhausia intermedia (Eigenmann)(Pisces, Characiformes) in Itumbiara Reservoir, Goiás, Brazil. Rev. Brasil. Zool. 21(3), 519-524.

Lahnsteiner, F., Nussbaumer, B., Patzner, R. A. (1993), Unusual testicular accessory organs, the testicular blind pounches of blennies (Teleostei, Blenniidae). Fine structure, (enzyme-) histochemistry and possible functions. J. Fish Biol., 42, 227-241.

Lau, P. P. F., Sadovy, Y. (2001), Gonad structure and sexual pattern in two threadfin breams and possible function of the dorsal accessory duct. J. Fish Bio., 58, 1483-1453.

Le Cren, E. D. (1951), The length-weigth relationship and seasonal cycle gonad weigth and condition in the perch (Perca fluviatilis). J. Anim .Ecol., 20, 201-219.

Matta, S. L. P., Santos, A. A., Andrade, D. R. (1994), Distribuição de colágeno e fibras conjuntivas no ovário do lambari-bocarra Oligosarcus argenteus (Gunther, 1864)(Pisces, Characidae). In-Encontro da Associação Mineira de Aqüicultura.

Mazzoni, R., Caramaschi, E. P., Fenerich-Verani, N. (2002), Reproductive biology of a characidiinae (Osteichtyes, Characidae) from the Ubatiba River, Maricá - RJ. Braz. J. Biol., 62(3), 487-494

Menezes, N. A. (1972), Distribuição e origem da fauna de peixes de água doce das grandes bacias fluviais do Brasil. In-Comissão Interestadual da Bacia ParanáUruguai. Poluição e Piscicultura. São Paulo, Faculdade de Saúde Pública da Universidade de São Paulo. 73-8.

Modesto, T, Canário, A. V. M. (2002), Morphometric changes and sex steroids levels during the annual reproductive cycle of the Lusitanian toadfish, Halobatrachus didactylus. Gen. Comp. Endoc., 131, 220-231.

Neves, C. A., Vidal Jr, M. V., Andrade, D. R., Matta, S. L. P., Santos, A. A. (1991), Histoquímica dos polissacarídeos dos ovócitos IV do lambari-bocarra (Oligosarcus argenteus Gunther, 1864). Encontro Anual da Associação Mineira de Aqüicultura, 1, 4041.

Neves, C. A., Andrade, D. R., Matta, S. L. P., Vidal Jr, M. V., Santos, A. A. (1995), Cytochemical analysis of polysaccharides from the cortical alveoli of the lambari-bocarra (Oligosarcus argenteus Gunther, 1864)(Pisces, Characidae). Rev. Bras. Biol., 55(4), 693-696

Neves, C. A., Andrade, D. R., Matta, S. L. P., Vidal Jr, M. V., Santos, A. A. (1996), The zona pellucida of the freshwater fish Oligosarcus argenteus Gunther, 1864 (Pisces, Characidae): a cytochemical study. Arq. Bras. Med. Vet. Zootec., 48, Supl.1, 25-32

Patzner, R. A. (1989), Morphology of the male reproductive systems of two Indopacific blennid fishes, Salarias fasciatus and Ecsenius bicolor 
(Blennidae, Teleostei). Z. Zool. Syst. Evolut.-forsch, 27, 135-141.

Patzner, R. A.; Seiwald, M.; Angerer, S.; Ferrero, E. A.; Giulianini, P. G. (1991), Genital system and reproductive cycle of the male grass goby, Zosterisessor ophiocephalus (Teleostei, Gobiidae), in the northern Adriatic sea. Zool. Anz., 226(5/6): 205219.

Pecio, A. and Rafinski, J. (1994), Structure of the testes, spermatozoa and spermatozeugmata of Mimagoniates barberi Regan, 1907 (Teleostei: Characidae), an internally fertilizing, oviparous fish. Acta Zool., 75(3), 179-185

Sala, M.A.; Mateus, M; Valeri, V. (1982), Princípios básicos e aplicações da estereologia em morfologia. Ci. Cult., 34(3): 305-312.

Santos, A. A. (1993), Morfologia microscópica do ovário de Oligosarcus argenteus Gunther, 1864 (Pisces: Characidae). Monografia, Universidade Federal de Viçosa, Viçosa, Brasil

Santos, A. A., Matta, S. L. P., Andrade, D. R. (1995), Época e tipo de desova de lambari Oligosarcus argenteus. Anais do Encontro Brasileiro de Ictiologia, G4-G4.

Santos, J. E., Bazzoli, N., Rizzo, E., Santos, G. B. (2004), Reproduction of the catfish Iheringichthys labrosus (Lütken)(Pisces, Siluriformes) in Furnas Reservoir, Minas Gerais, Brazil. Rev. Brasil. Zool 21(2), 193-200.

Schifino, L. C., Fialho C. B., Verani J. R. (2004), Fish community composition, seasonality and abundance in Fortaleza Lagoon, Cidreira. Braz. Arch. Biol. Technol., 47(5), 755-763.

Schulz, U. H., Martins-Junior, H. (2001). Astyanax fasciatus as bioindicator of water pollution of Rio dos Sinos, RS, Brazil. Braz. J. Biol., 61(4), 615-622.
Silva, M. (1987), Morfologia ultra-estrutural do testículo, cinética da espermatogênese e barreira hemo-testicular da tilápia do Nilo Oreochromis niloticus (Peixe, Ciclídeo). Tese de Doutorado, Instituto de Ciências Biológicas da Universidade Federal de Minas Gerais, Belo Horizonte, Brasil.

Silva, J. V. (1990), Utilização de insetos e ração na alimentação de lambari-bocarra, Oligosarcus argenteus Gunther, 1864 (Pisces: Characidae), em gaiolas. Tese de Mestrado, Universidade Federal de Viçosa, Viçosa, Brasil.

Siqueira-Souza, F. K, Freitas, C. E. C. (2004), Fish diversity of floodplain lakes on the lower stretch of the Solimões River. Braz. J. Biol. 64(3A): 501-510

Souza, J. R. and Andrade, D. R. (1984), Produção de lambari-bocarra (Oligosarcus argenteus) (Pisces: Characidae) em cativeiro. Revista Ceres, 31(176), 310-312.

Tavares, E. F. (1986), Biologia reprodutiva do piaugordura Leporinus piau Fowler, 1941 (Pisces, Anostomidae) da Represa de Três Marias, Rio São Francisco, MG. Tese de Mestrado, Instituto de Ciências Biológicas da universidade Federal de Minas Gerais, Belo Horizonte, Brasil.

Uieda, V. S., Uieda, W. (2001). Species composition and spatial distribution of a stream fish assemblage in the east coast of Brazil: comparison of two field study methodologies. Braz. J. Biol., 61(3): 377-388.

Van Der Hurk, R.; Resink, J. W.; Peute, J. (1987), The seminal vesicle of the African catfish, Claria gariepinus. Cel. Tissue Res., 247, 573-582.

Vazzoler, A. E. M. M. (1996), In-Biologia da reprodução de peixes teleósteos: teoria e prática, ed. EDUEM Maringá, pp. 169.

Received: May 18, 2006; Revised: February 07, 2007; Accepted: September 17, 2008. 